$\begin{array}{ll}\text { Variants } & \begin{array}{l}\text { Variants } \\ \text { The Journal of the European Society for Textual } \\ \text { Scholarship }\end{array}\end{array}$

15-16 | 2021

Textual Scholarship in the Twenty-First Century

\title{
On the Threshold of Editorship. Or From Collection to Oeuvre
}

\section{Paulius V. Subačius}

\section{OpenEdition \\ Journals}

Electronic version

URL: https://journals.openedition.org/variants/1375

DOI: 10.4000/variants. 1375

ISSN: 1879-6095

\section{Publisher}

European Society for Textual Scholarship

\section{Printed version}

Date of publication: 1 July 2021

Number of pages: 81-104

ISSN: 1573-3084

\section{Electronic reference}

Paulius V. Subačius, "On the Threshold of Editorship. Or From Collection to Oeuvre", Variants [Online], 15-16 | 2021, Online since 01 July 2021, connection on 13 September 2021. URL: http:// journals.openedition.org/variants/1375 ; DOI: https://doi.org/10.4000/variants.1375 


\title{
On the Threshold of Editorship. Or From Collection to Oeuvre
}

Paulius V. Subačius

\begin{abstract}
The sole collection of verses by Jonas Mačiulis (1862-1932, pen name Maironis), the father of modern Lithuanian poetry, went through five editions in the author's lifetime. The poet continued to improve the works of his youth until his advanced age, producing hundreds of textual variants. The first published versions of some verses, which are ranked as national classics today, cannot be considered finely crafted works by a long shot. From a retrospective point of view, one is surprised that such lengthy and tedious corrections could have yielded such nice final results, while a prospective approach might incite amazement at how the crude, primary rock of first versions could have concealed the possibility of such poetic gems. Taking a grandmotherly attitude towards his works, the author did not only polish their versification, but also applied different strategies throughout his rewriting process to use new editions to consolidate his own social and cultural position with the changeable standards of bibliographic codes over time. The problem editors of the Maironis' posthumous editions face is that the authorial editions of his works differ in title, textual variants, and arrangement. As this article argues, both Maironis' high standing in the Lithuanian cultural landscape and the elusive expectation of stability and comprehensiveness have discouraged editors to plunge into the dynamic nature of Maironis' authorial manipulations up until today.
\end{abstract}

THERE ARE VARIOUS STORIES of how prominent works were written and published, but most of them understandably contain common traits. ${ }^{*}$ The first of these would be the fact that most revisions remain unknown to readers until their manuscripts are analysed posthumously - since authors usually try to publish completed versions. The exception to this rule would be when versions printed in periodicals are followed by different versions in book editions, or when authors altered their already successfully circulating works for an edition of their oeuvre or selected works to summarize their writing careers. While textual instability is regarded as "a fact of life" by contemporary theorists (Shillingsburg 2017. 194), authors have long preferred to conceal this fact, rather than present it as a goal of their authorship ${ }^{1}$

* This research was funded by a grant (No. S-MOD-17-7) from the Research Council of Lithuania.

1 In fact, we know that authors were even required to withdraw their earlier versions upon publishing of a new version at least since classical antiquity (see Reynolds 
Another feature of our common assumptions towards the origins of famous works would be the value we tend to place on them. There is another end to the stick in the teleological approach to the creative process, as has been discussed by genetic critics (see Bushell 2005, 56). If a purposeful relation exists between a work's earliest drafts and its published text, and if the writing and revision processes moving in the direction of a final entity, it is only natural that we also have a look in the reverse direction. In hindsight, a successful result invites the presumption that - at least to a certain degree - the work's creative potential was already inherent in the earliest variants, which are not only endowed with historical value in the process, but also with aesthetic value by omission.

However, reality does not always comply with these presuppositions. How do they reshape our understanding of the way in which literature functions? Do textual critics or editors have any means, not unlike mineralogists, to perceive and reveal polishable crystalline structures that are deeply hidden in immature texts? Or do we perhaps only attribute the status of a "variant" or "source" to a primitive sequence of words once we know how valuable the final result is? How do we represent the entire genesis of a work if the author himself changed his attitude towards the work several times along the way, and applied several different strategies to use it for the consolidation of his social and cultural position? Some of these questions will remain rhetorical throughout this essay, intending to inspire further analysis. If I succeed in revealing the complexity of editorial situations, we may only come some steps closer to devising simplified answers to these questions. Nevertheless, the potential of digital archives when it comes to communicating the wholeness of works with complicated geneses to a contemporary audience makes me optimistic for the future.

In this essay, I will discuss these issues by investigating the case of a Lithuanian writer known under the pseudonym of Maironis. Jonas Mačiulis (1862-1932), a priest, professor of theology and historian, used this pen name to sign one of the first publications of his poems in a clandestine periodical (Maironis 1891b). He became an icon of the national revival and was already proclaimed the central figure of modern Lithuanian literature during his lifetime in the early 20th century (Šeina 2016, 54-55). This official assessment of the poet has not changed in the last century (see Kalnačs 2009. 184-87). Shortly after his death, Maironis' house was converted into the national museum of Lithuanian literature. A 20-litas banknote issued by the Bank of Lithuania, which was in circulation from 1993 to 2014 (at which point the national currency was replaced by the Euro), bears his portrait.

Maironis wrote narrative poetry, dramas, and librettos, but it were his poems that won him the status of a classic. Because the tsarist administration forbade the press to use Latin characters in the 1860s in an attempt to introduce the Cyrillic script, Lithuanian newspapers were published abroad and secretly smuggled into the country until 1904. Having published eleven poems in these newspapers, Maironis illegally published a book of his poetry in 1895 (Maironis 1895a).

and Wilson 1991, 24). 
To this day, this collection of verses - the name of which (Pavasario balsai [The Voices of Spring]) symbolized the rebirth of the nation's typical nationalism remains the most important form for circulating his poetry. At the time of publication, Maironis already had two published books on his record: one a narrative of the history of Lithuania (Maironis 1891a), the other an epic poem with social overtones Tarp skausmu i garbe [Through Pain to Glory] (Maironis 1895b). However, it was The Voices of Spring that paved the way to his role as a national writer. Having realized this, the poet would later cling to the same perfectly recognizable figurative title, and published three more collections of his poems appeared as The Voices of Spring in his lifetime (Maironis 1905: 1913: 1920). In addition, a total of 30 posthumous editions of Maironis' poems in Lithuanian were published as The Voices of Spring (the latest one only yesteryear: see Maironis 2020) ${ }^{2}$ In this sense, Maironis is a poet who is identified with a sole collection of poems (Daujotyte 1990, 62). None of the classics of national revival in the surrounding countries (Janis Rainis in Latvia, Lydia Koidula in Estonia, Taras Shevchenko in Ukraine) were identified so directly with one title except for Belarusian short-lived Maksim Bahdanovich (1891-1917), whose collection of poems Vianok [A Wreath] (1914) was his only book of poetry.

It is worth mentioning that when Maironis chose The Voices of Spring as a stable brand name (cf. Kučinskienè 2014, 251 and 257), this decision was exclusively of symbolic rather than financial value. The publishers' interests and opinions only played a minimal role here, since the publications were funded by the author himself, and by Catholic societies. Due to the political restrictions of that time, the only thing that the author may have earned from the first edition of his collection of poems was a deportation to Siberia. Later, when the ban on the press in Latin characters was withdrawn, he held well-paid positions of professor of the Theological Academy and rector of the Seminary; thus remuneration for his creative work was not and could not have been a source of income and an underlying motive for this activity.

2 The penultimate edition was marked as $28^{\text {th }}$ (Maironis 2012), but for some editions the numbering indicated in their subtitle does not coincide with their actual numbering in the sequence identified by Maronis' bibliographers. In a discussion following my presentation on this collection of poems at the $26^{\text {th }}$ annual SHARP conference "From First to Last: Texts, Creators, Readers, Agents" (Western Sidney University, 2018), Paul Eggert noted that such a large number of re-editions of a poetry book in nine decades is phenomenal, particularly bearing in mind the relatively small Lithuanian readership (of $\sim 3.5$ mil persons), and the fact that Maironis was hardly known beyond the national borders. It should be noted that the poet was indeed popular, but that social and political circumstances rather than financial interest played an important role in this process of re-editing his works: the community of Lithuanians in exile in the USA, Germany, and Italy (separated from Luthuania in the cold war) were instrumental in publishing a series of local non-commercial editions to provide teaching materials for Lithuanian courses and Saturday schools. In addition, during Nazi and especially Soviet occupations, the government had to replace the editions with more ideologically appropriate ones, and some of the poems were censored out. That is why, after the change of the regime in 1990, editors aimed to publish more complete collections of Maironis' poetry. 
However, The Voices of Spring did not remain the only form in which Maironis published his collection of poems. Here we can talk about his secondary initiation: his initiation to the classics. Six years before his death, Maironis edited the first volume of his Oeuvre dedicated to verses he chose himself and financed with his own means ${ }^{3}$ He did not resume the tradition of The Voices of Spring and titled it Lyrika [Lyrics] (Maironis 1927) 4 The latter title expressed the idea that Maironis' works could be regarded as a poetic standard for Lithuanian literature in general.

A more intense alteration of the poetry collection rises to the surface when we look at the authorial use of The Voices of Spring from the viewpoint suggested by William Stroebel when he reflected on Constantine Cavafy's collections: "not as a one-way communication device broadcasting the poet's final intentions but as a kind of ongoing, open workshop, one that continually suspended the finality of its own production and extended the processes of inscription, assemblage, and re-assemblage" (Stroebel 2018, 280). Extremely important were the transformation of the arrangement of texts and the revisions in the poems themselves. In the case under discussion, a single collection of poems does not exactly equal a collection of the same poems. The Voices of Spring underwent considerable changes in the poet's lifetime. Having gone through five editions, it increased three times from 45 to 131 poems; four poems were once included in the collection, once removed from it by the author's will.

Far more significant were the revisions in the poems themselves. Even in those few poems that underwent relatively few alterations by the author, the spelling was edited and some words or forms were replaced. The poem "Nuo Birutès kalno" [From Birute Hill] $\left.\right|^{5}$ included in all the editions of the poetry collection, contains the least amount of revisions. In the author's last version it has 16 lines, 106 words and 535 letters (including the title). During thirty-two years of revising, in five versions published by Maironis himself, seven words, eleven morphophonological forms, five punctuation marks, and twenty-eight cases of spelling were changed 6 While the latter variants are accidentals, the first ones are undoubtedly substantials.

3 This was not a unique case at that time in Lithuania: by 1927, eight living writers had republished or began to republish their works, specifically under the title Oeuvre. Two of them (Juozas Tumas, penname Vaižgantas and Kazimieras Pakalniškis) were friends of Maironis.

4 "Sixth edition" is added under the title, thus indicating a direct link to the editions of The Voices of Spring. Bibliographically, Vol. 1 of Oeuvre should be the fifth edition of Maironis' poetry, but the second edition of The Voices of Spring of 1905 was published with a reference that it was the third edition (as the short play Kame išganymas (Where is the Salvation) included in the book after the poems was indeed published for the third time), and this is how this erroneous sequence became established.

$5 \quad$ Here and hereafter I use the traditional titles from the 1927 edition to identify the poems since Maironis had revised them many times.

6 From this account were excluded variants that originated as the result of three presumed typographical errors in the 1895 edition, and three typographical errors in the 1927 edition. 
What then does the versioning of considerably more revised poems look like? The best poem to illustrate this issue would be "Lietuva brangi" [Dear Lithuania], which has acquired the status of the second, unofficial, anthem of Lithuania, and is widely learned by heart and sung, which makes it one of the most popular and famous works by Maironis. First published in a newspaper, the poem consisted of 16 stanzas and 62 lines (Maironis 1891c), while the author's last version had 8 stanzas and 32 lines (Maironis 1927, 58-59). It is only from single words or motifs that one can approximately guess which stanzas of the early version were transformed into later variants, as not a single line of the initial text coincides with the revised one. Not even a hint of eight lines of the last version appears in the first publication. In all the other lines both some words and the word order is changed without exception. If we compare the publications revised by the author from a morphophonological point of view, as few as 40 , or one-fourth of 160 words of the latest text coincide with the first version of the poem. If we add the differences in punctuation and spelling, we could say that while revising "Dear Lithuania", the poet left a mere $10 \%$ of the text intact 7

Many revisions were made to achieve more fluent versification. Historians of literature unanimously assert that Maironis was the first Lithuanian poet to use syllabo-tonic versification perfectly, and achieved a high level of poetical precision. In other words, metric schemes are retained in his poems; moreover, they are not in conflict with the regular accentuation of words and syntactic combinations, which helps to achieve a harmonious sound. These statements hold up when analyzing the latest versions revised by the author - the first stanza of "Dear Lithuania" (Maironis 1927, 58) is an example of a precise iambic foot with a hypercatalectic caesura (Girdzijauskas 1966, 234-5):

$$
\begin{aligned}
& u-\cup-\cup \| \cup-\cup-u \\
& u-\cup-\cup \| \cup-\cup-u \\
& u-\cup-\cup \| \cup-\cup-u \\
& u-\cup-\cup \| \cup-\cup-u
\end{aligned}
$$

In the initial version, by contrast, the first stanza's metric scheme goes as follows - respecting the natural accents of the words in standard Lithuanian (Maironis 1891b):

$$
\begin{aligned}
& -\cup \cup-\cup \|-\cup \cup-\cup \\
& \cup-\cup-\cup \| \cup \cup--\cup \\
& \cup-\cup \cup-\| \cup-\cup-\cup \\
& \cup-\cup-\cup \|-\cup \cup-\cup
\end{aligned}
$$

$7 \quad$ I am using statistics not only because it is quite convenient, but also because a much more extensive paper would be needed in order to present adequate translations of the variants and to compare them. For published samples of Maironis' poetry translations into English, see Maironis 1963 and Maironis 2002 
The irregularity here is quite obvious, and has been eradicated in subsequent versions through careful polishing. In fact, many of Maironis' first publications contained versification errors, which were then successfully avoided in later versions. On the one hand, there is no doubt that Maironis could write much more fluent verses than other contemporary poets right from the start. On the other, a retrospective view of the classical qualities of his poetry found in textbooks and works on the history of literature has a certain inconsistency: the final self-revised versions are quoted as proofs of his poetic elegance, even though the topic of discussion is the young Maironis and the first edition of The Voices of Spring in 1895 (Zaborskaite 1987. 98), which still contains a large number of sharp edges.

By using a uniform title for the collections of poetry, Maironis - perhaps unintentionally - set up the preconditions for his posterior literary critics to paint him as a greater literary pioneer than he really was. This happened because when critics were analyzing the poems Maironis had written in the 1910s, which were included in the fourth edition of The Voices of Spring, the newer versions of these poems were mistakenly attributed to the late nineteenth century - when their first edition had been published. Due to very rapid changes that took place in Lithuania, this quarter-of-a-century anachronism was more than enough to make Maironis appear as an example to other writers of the first half of the twentieth century, even though this image was partly based on impressions of poems that were (re)written at the same time or even later than their works. National ambitions spurred the declarations that as early as 1895 , Lithuanian literature already had a classical author who wrote poems of refined lyrical form.

When we address another type of Maironis' self-revisions, an even more distinct shadow of anachronism looms over the critics' remarks on the poet's modernity. This is because the four decades over which his career spans also coincide with the period where the most intense formation of the standard Lithuanian language took place. Already after the first publications of his poems in the periodical press, publishers generally came to a final agreement regarding several new letters of the Lithuanian alphabet $(\mathrm{sz} \rightarrow \check{\mathrm{s}} ; \mathrm{cz} \rightarrow \check{\mathrm{c}} ; \dot{\mathrm{z}}, \mathrm{z} \rightarrow \check{\mathrm{z}}$; $\overline{\mathrm{e}} \rightarrow \dot{\mathrm{e}} ; \mathrm{u}[\mathrm{u}:] \rightarrow \overline{\mathrm{u}} / \mathrm{u} ;$ Venckienè 2006, 38-39). In other words, it was necessary to transliterate the early versions of his poems in subsequent publications. The first edition of The Voices of Spring was followed by a textbook of Lithuanian grammar (Jablonskis 1901), which established the principles of selection of prescriptive paradigms from a variety of dialects and their contemporary orthographic rules. In other words, part of the morphophonological forms, spelling and punctuation had to be revised, bit by bit, in each subsequent edition of Maironis' 1895 collection (Venckienè 2012. 204-05). In the last period of Maironis' creative work, after the declaration of independence in 1918, the new state was quick to build a system of general education, and to promote the publishing and other forms of communication in the official Lithuanian language. Therefore, the removal of the dialectal vocabulary and morphological inconsistencies, as well as the 
establishment of the standards of accentuation and pronunciation of the language used in a cultured urban milieu, was taking place very rapidly. Although Maironis relied on himself rather than editors even for minor corrections, it is obvious that only the author himself could revise the poems and fully adapt them linguistically to standard modern usage.

In many cases, the rejection of dialectal forms also meant approaching regular standard accentuation - ergo, a more precise metre, and vice versa. However, I dare to assert that doubt in the motivation for one or another revision does not deny Maironis' basic tendency to adapt his writings to the changing language standard. These assumptions imply a methodological remark about a prospective genetic digital edition of Maironis' poetry. I suggest that in such an edition it would be important to demonstrate the chronology of the appearance, inclusion, and disappearance or removal from standard use of the linguistic features found in the texts along with the change of variants. In addition, historical sociolinguistic information would be very useful - explaining which lexemes and forms became popular or prestigious, when and in which socio-cultural contexts these changes took place, etc. (cf. Venckienè 2018, 230). It does not occur so frequently that the peak of language standardization would coincide with the period of the creative career of a prominent writer, during which the latter would intensely (and, importantly, successfully) revise his texts in every decade. The main difficulty is that such an undertaking requires detailed data of language history.

Let us take a brief detour into a wider socio-cultural context - the development of the modern Lithuanian national identity. Here, we can again state an important chronological coincidence between important events and different stages of self-revision of Maironis' poetry. The second edition of The Voices of Spring, for example, appeared in 1905 - the year of the Russian revolution, when the social atmosphere became considerably freer. And the fourth edition was prepared right after the Republic of Lithuania proclaimed its independence. In both cases, new ideological accents can be indicated in the poems. Finally, the last authorial edition of the Oeuvre coincided with the abolishing of the state's parliamentary democracy. In the period of the authoritarian rule of the president and ideologist of nationalism Antanas Smetona (1874-1944), which lasted from 1926 to 1940, the exemplary collection of national symbols and the historical narrative promoted in schools acquired its final stable shape ${ }^{8}$ Reciprocal influence should be borne in mind - Maironis textually reacted to the birth of the national state and, in its turn, his poetry was simultaneously popularized as texts that unified society.

A short remark on a factor that might seem to counteract the drive for authorial revisions: several of Maironis first published poems had already been set to music. At first, they were adapted for folk melodies, and later performed to music

8 Due to the Soviet occupation, it remained partially conserved up until 1990, and still has a huge influence on the self-consciousness of the older and middle generations even in our days. 
created by professionals. Two of the most prominent Lithuanian composers of that time, Juozas Naujalis (1869-1934) and Česlovas Sasnauskas (1867-1916), composed songs for mixed choirs to twenty-three poems from The Voices of Spring. After 1905, when the tsarist administration stopped interfering with public national events, they began to be performed on a massive scale. Songs that were performed during Lithuanian gatherings rapidly became extremely popular. The author himself both cooperated with the composers and took part in these events - an amateur musician himself, who held recitals at his home. On the one hand, more fluent poems that had already been more refined with regard to versification in the early stages of their development were set to music. Such texts were then revised less by the author when he prepared subsequent editions of the collection. On the other hand, this aspect alone can hardly explain the fact that it were especially the poems that had been set to music that Maironis avoided revising. A juxtaposition of the text and its melodic accents reveals that the latter stabilized the text, therefore the idea about the conserving role of music should be borne in mind in this case. The interaction of the melodies and the texts of the early edition, as well as the inertia of performance when choir singers committed the text to memory, along with the motility of singing counteracted the scale of a more radical authorial alteration.

A look at the revisions that Maironis made in order to adapt to the rapidly changing language and society prompts another observation, namely that any attempt to describe his relation with cultural modernization contains an internal contradiction. The well-established statement by literary critics that Maironis brought a modern poetic language into Lithuanian literature (NykaNiliūnas 1962, 286) is both correct and misleading. The poet resourcefully used the form of the language that existed at the time of writing, and contributed to its further development along the way. Maironis was modern in each stage of writing and revision: the linguistic expression of his poetry corresponded to the state of the cultural medium for approximately a decade until a subsequent revised edition of The Voices of Spring came out. However, from our contemporary perspective the texts of the first publications do not seem to be written in the modern Lithuanian language. On the other hand, since the state of the standard Lithuanian language, which was settled in the late 1920s, did not experience more radical changes in the fields of morphology and accentuation, Maironis' latest self-revised versions do not seem ancient, and the texts are read as if they "have lost the vestiges of time" (Žvirgždas 2012, 37). One or two remaining archaisms, mainly lexical, add the sheen of nobility that is characteristic of classical works, but do not impede an easy reading of the works as modern texts. Probably that is why the topic of the development of Maironis' poetry seems strongly overlooked even in the Lithuanian context, where the critics' attention to textual variants and self-revision is extremely scarce in general. They almost seem like intuitive attempts to prevent a wide audience from discovering a more archaic Maironis, so as not to tarnish his image as a modern poet.

Another aspect of his image - the halo of solidity, stability, and wholeness 
(cf. Slavinskaite 1987, 15) - contradicts what we know about the numerous revisions of his texts. An afflatus would be much more befitting to a poet of overdue Lithuanian Romanticism than the meticulous labour of adjusting their metre to perfection. In Maironis' case a distinct dissonance of reflection was provoked by the fact that when he published his last self-revised versions in 1927. his poetry had not only been an obligatory read, but had also already occupied one of the top positions in schools' curricula for a decade. In other words, a generation of students who knew at least a dozen of Maironis' poems by heart from their school years, experienced having to correct their memory and apparently discard the lines which had stuck in their minds.

In any event, authorized polyvariance has remained a potential aporia of reception. Naive lovers of Maironis' poetry felt quite embarrassed when the early versions of well-known poems were reprinted in commemoration of the centennial anniversary of the first edition of The Voices of Spring (Maironis 1995). Readers failed to accept an imperfect, unpolished classic. In the meantime, in order to trace the genesis of Maironis' most significant stanzas, one would have to take an even larger step back. It is not difficult to recognize the rudiments of the already mentioned poem-anthem "Dear Lithuania" and several other poems - separate lines, phrases, motifs and models of strophes - in his earliest work "Lietuva" [Lithuania] (Maironis 1888). This descriptive long poem of loose structure, which is more reminiscent of a bundle of verses on the topic of nature and history, was written by Maironis at the age of twenty-six and never published. It was not until the end of the twentieth century that it was included as a supplement to the second volume of Oeuvre containing narrative poems (Maironis 1988).

Many writers refrain from publishing their first creative attempts, because they consider them immature. Maironis' "Lithuania", however, is not merely an early attempt at versification: it is an agglomeration of the rudimentary elements of his entire poetics. Maironis was noted for a kind of "economy" of motifs (Speičytè 2012, 81). For the entirety of his literary career, he made use of a limited array of images, which appeared already in his first verses, and with each edition produced an increasingly stronger poetic effect due to the constant refinement of the texts. A few known rough copies testify that even in his mature age, Maironis would start a new work from a very weak version with a chaotic metre and non-matching rhymes, which would significantly improve after several revisions (Maironis 1925). A genetic edition could demonstrate the acting of the agency that transformed a bad poem into several particularly good poetic works. The genetic dossier of Maironis' verses poses a serious challenge to the premises of afflatus, which is particularly intriguing bearing in mind the fact that the poet was a priest. The scrutiny of the succession of textual transformations compels us to think that the poet's entire activity was geared towards perfecting his craftsmanship. Still, a reader remains perturbed by occasionally glimmering traces of irreducible creativity.

Eventually, there is a serious dissonance between the two self-editing ten- 
dencies that are typical of Maironis: 1) he was never satisfied with the result, intensely reworking his poems for each new publication; and 2) in several cases, he omitted the unsuccessful verses, while never completely discarding even the weakest of his already published works, but rather including all of them in the collections and Oeuvre. For example, being unable to deal with the compositional heterogeneity of one of his early poems, "Lietuvos vargas" [Misery of Lithuania] (Maironis 1885), he simply split it up, and included it in Oeuvre as two separate works (Maironis 1927, 50-51). As such, the whole remained very diverse, lacking harmony and refinement, and even had several inlays of tastelessness (Sauka 1998, 80). On the one hand, this almost freed Maironis' subsequent editors from the need to collect the poems that were scattered in periodicals and manuscripts, discarded or forgotten by the author, which the compilers of the posthumous opera omnia often confront, and find one way or another to arrange them all into a comprehensive whole 9 On the other hand, this was offset by serious complications for his editors, as he left a legacy of two alternative titles of his collected poetry The Voices of Spring and Lyrics, and kept altering the sequence of their individual poems.

To illustrate this problem, I must describe the process of composing The Voices of Spring at length. Despite the difficult circumstances of publishing illegally and abroad, we can already recognize the authorial arrangement of the sequence of poems in the first edition of the collection, which allows us to consider it as a structurally coherent work. Historians of literature assert that Maironis formed thirteen quasi-sections according to the thematic or genre affinity (hymns, sonnets, satires; Speičytè 2019. cf. Pokorska-Iwaniuk 2014). This is merely an interpretative observation, as the poet did not introduce chapter headings (with the exception of the Sonnets chapter that appeared in the 1913 and 1920 editions); nor do the first and subsequent editions contain any obvious graphic divisions. However, the grouping is evident and is confirmed by the further development of The Voices of Spring. The fact remains that in three subsequent editions, when he added new poems to the collection, Maironis inserted them in the existing groups, consistently following the principle of thematic and genre affinity. With very few exceptions, he did not change the sequence of the already published poems and quasi-sections, but rather expanded the latter every time. This means that the principal structure of the collection of poetry was stable. For a graphical representation, see Figure 1 .

While preparing a new edition for print, the poet would make revisions to the already published poems in a personal copy of the previous edition. He would write down additions, or attach them on a separate sheet, and renumber the poems by hand, indicating their sequence for the typesetter. There is a

9 Only fifteen of the known poetic works did not make their way to Oeuvre of 1927 nine verses written after the compilation of Oeuvre, three excerpts of the narrative poem "Mūsų vargai" [Our Hardships] that were included in The Voices of Spring of 1920 as separate pieces, and two poems that previously appeared only in the periodicals and one verse published in The Voices of Spring. 


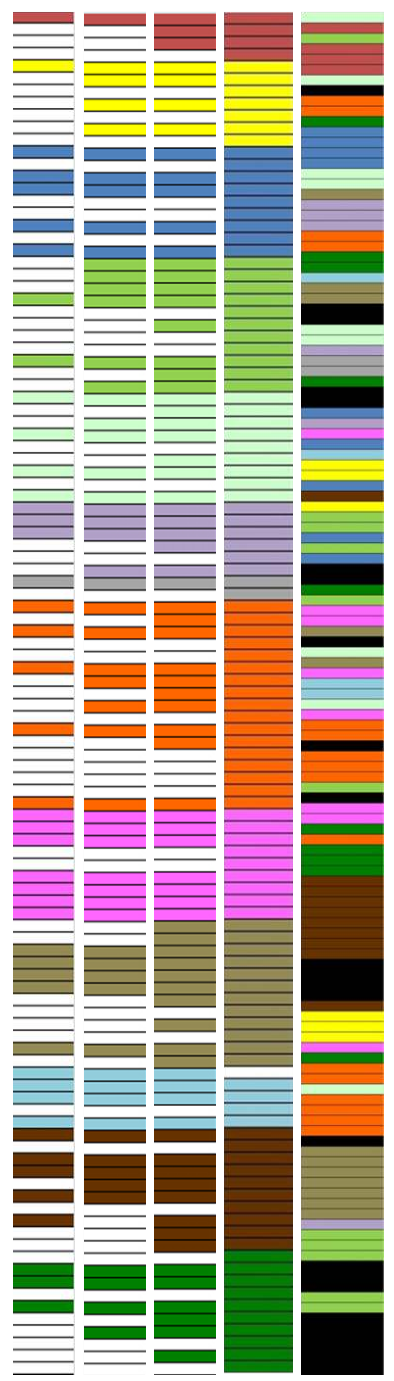

Figure 1: Composition of the collection The Voices of Spring (Speičytè 2019. 133-41) and Oeuvre. In this representation, each rectangle, except for the white ones, represents a poem; their colours represent the quasi-sections they belong to; and black rectangles represent new poems in the Oeuvre. From left to right, they represent the editions of $1895 \mathrm{a}$ (45 poems), 1905 (57 poems), 1913 (78 poems), 1920 (110 poems), and 1927(131 poems). This graphic shows how each of the quasi-sections grows over time, to be ultimately reshuffled in the 1927 edition. 


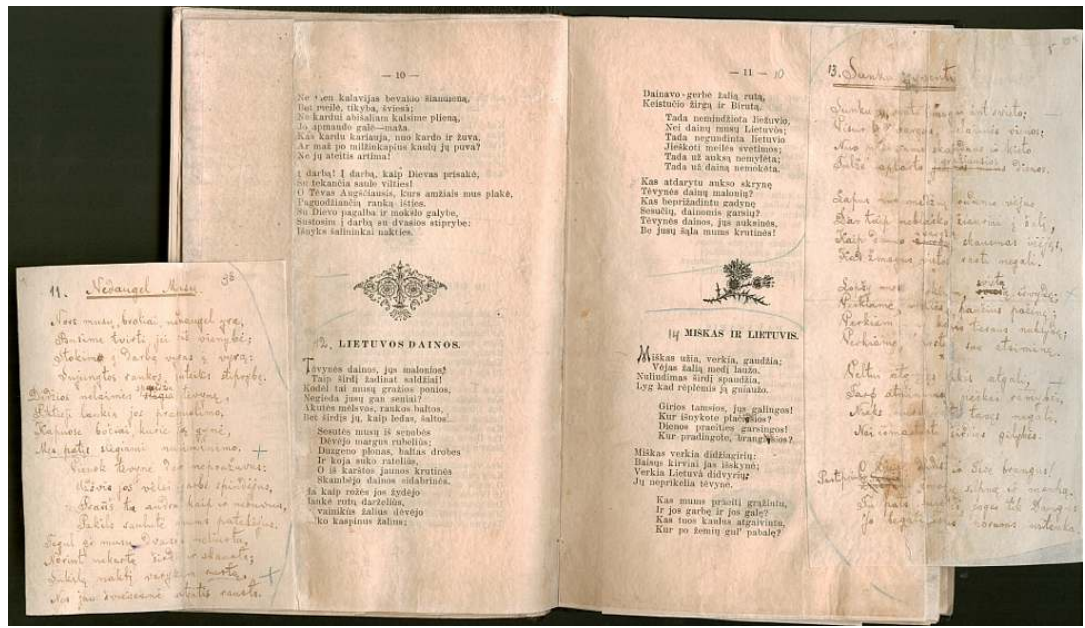

Figure 2: Authorial additions and revisions in Maironis 1918, pages 10-11.

surviving publisher's copy of The Voices of Spring from 1920, which the poet himself produced from a copy of the 1913 edition "with a pair of scissors and glue" (Maironis 1918, see Figure 2), and a copy of The Voices of Spring from 1920. from which Maironis prepared a rough copy for Oeuvre Maironis 1926 in the same way.

Maironis' Oeuvre was supplemented with nineteen new poems; other works were finally adapted to standard Lithuanian as already discussed. Moreover, the author radically changed the former sequence of the poems by disrupting most quasi-sections, thematic groups and the previous framing composition of the beginning and end of the collection based on patriotic accents (see Figure 1. The cyclical nature of The Voices of Spring should be realized not only as the thematic grouping of the works. The opening poems of each group provide a certain key to the reading of other works, and the series function as parables. For example, "Jo pirmoji meilè" ("His first love") that opens the collections signals "the love that the lyrical self feels for Lithuania." By doing so, several further nature or love poems already imply a national-patriotic statement. In Oeuvre, the author disrupted "the cycle of poems with its allegorical structure and its decoding technique" (Kessler 2014. 69), as presumably the key was no longer necessary: the codes of reading the classic Maironis were imposed by the expanding tradition of interpretation, school textbooks, and broadcast songs with his lyrics. This new structure of Oeuvre was oriented to literary eternity, and its framing composition consisted of works on universal and existential rather than patriotic themes.

As Peter Shillingsburg suggests, Hershel Parker made a sceptical presumption 
in his Flawed Texts and Verbal Icons (1983) that "authors lose their authority over a work after a certain period and that revision often not only violates the creativity of the original effort but can end in confusion which might make a text unreadable" (Shillingsburg 1991, 70). In the case of Maironis, this idea would argue against the latest authorial versions of the poems (in which the best versification was achieved). From the point of view of general composition, however, the collection of The Voices of Spring was more coherent than the volume of Oeuvre. In any case, it should be noted that from an editorial perspective the collection and Oeuvre differ both in their use of textual versions, and in the number and especially the arrangement of poems.

In the years of World War II (and soon afterwards) the first eight posthumous editions of Maironis' poetry were published in Lithuania, and by war refugees and displaced persons in Germany (Meerbeck and Würzburg) under the title The Voices of Spring. Three of these editions did not reach their readership: two were suspended and destroyed by Soviet censors, and one perished during the bombing of Weimar. Although each of these eight editions are slightly different ${ }^{10}$ all of them were compiled according to a model that was introduced by a single editor: Juozas Ambrazevičius (1903-1974; known as "Brazaitis" from 1944 onwards). He took the versions of the poems from Oeuvre, divided them into eight thematic or genre chapters, and even gave each chapter a heading, unlike any collection published in Maironis' lifetime (Maironis 1942). Although two groups of poems (i.e. the genre groups Satires and Ballads) can be detected both in The Voices of Spring from 1920 and in Oeuvre, in the above-mentioned editions of the 1940s type, the arrangement of poems within the groups did not correspond either to the first or the second authentic sequence as established by Maironis himself.

In the first edition of The Voices of Spring that was published in Soviet Lithuania (Maironis 1947), just like in all the other Soviet editions, 35 poems that contained religious motifs were discarded. However, in the context of this paper, I would like to draw attention to the aspects of the selection of versions and the structure of the collections rather than to this blatant act of censorship. In this case, it were the editors who made the structural decision to arrange the poems chronologically, and to divide them into three parts according to the periods of creative work. This way, they concealed their aim to disrupt the original division into quasi-sections that enhanced the manifestative effect of individual texts, and to present Maironis in the shape of historicized publication of literary heritage. Bearing in mind the general atmosphere of Stalin's regime and the ideological requirements that were imposed on all literature, including that of the past, this could be interpreted as an attempt to push a patriotic poet, albeit watered down, through Communist censorship. The dates written at each poem insistently reminded the readers that it was a thing from the bygone pre-revolutionary era, which should not be regarded as a source of relevant

10 For example, in some of them several poems about the struggle of Lithuanians with the Teutonic Order were removed in view of Hitler's censorship. 
motifs and ideas. As the poet himself precisely dated only one of his poems, this expansion of the peritext by dating all the poems made a historicizing (rather than aestheticizing) impact on the reading practice ${ }^{11}$ Moreover, for the lack of specialized research and reliable bibliography, the sequence of poems based on the first publications was imprecise with regard to the chronology of both writing the poems and their publication ${ }^{12}$ The versions of the texts were mainly taken from Oeuvre, but certain single variants from the 1905 and 1920 editions of The Voices of Spring were inserted rather eclectically: "in some places the primary version of particular stanzas or particular lines was restored" (Maironis 1947. 222).

A similar eclectic approach was used by the editor of The Voices of Spring of 1913 that was published in the emigration milieu in Rome in 1952. Taking the Oeuvre version as the basis, Bernardas Brazdžionis (1907-2002), a poet himself, inserted the variants of the 1920 edition in some stanzas and explained, "The restored old words or lines are very 'familiar' to us and have found a place in our hearts" (Brazdžionis 1952, 279-80). The phrase "in our hearts" was not just a poetic expression. When preparing the edition, Brazdžionis reverted to a common practice of philologists living the camps of displaced persons (1945-1950), who endeavoured to restore Lithuanian literary textbooks and anthologies without the use of books, by merely counting on what they knew by heart (Naujokaitis 1948, 5) 13 Ironically enough, in the editor's commentaries Brazdžionis denounced the above-mentioned Soviet edition of (Maironis 1947), alleging that in this edition the poems "were damaged, edited in a rather peculiar manner [...] of Soviet publications. [...] This kind of editing changes the shape and form of the collection" (Brazdžionis 1952, 294). In the Roman edition, eight chapters were introduced again, albeit different ones, that were arranged in another way than those published in the years of World War II. In addition, the sequence of the poems did not coincide with the structure of any edition prepared by Maironis himself.

An even stranger composition (already the sixth type of composition) appeared in an attempt to publish a semi-scholarly edition of Maironis' works, which included a discussion of the variants (Maironis 1982). In this edition, the first 36 poems were arranged in the sequence taken from the 1895 a edition of The Voices of Spring ${ }^{14}$ and then followed the poems that Maironis inserted

11 In the other Soviet editions, dates were also added, in some cases in square brackets (Maironis 1976. Maironis 1986).

12 For example, the poem "Mergaitè" [Girl] was erroneously dated to 1893 (Maironis 1986. 21), as the editors de visu did not check the reference found in bibliographies that it first appeared in Lietuviszkas Kalendorius metams 1894 turintiems 365 dienas, Vilniuje: Spauda ir iszdas Jůzapo Zavadzkio [counterfactual, should be: Tilžè: J. Šenkès sp.], 1893, p. 21. In fact, the anonymous verse (with identical title) published there should not be related to Maironis, and the above-mentioned poem by the latter was first published two years later (Maironis 1895a 34-35).

13 I would like to thank Jurga Dzikaite, who drew my attention to this fact.

14 This does not include the satires and texts with religious motifs, a total of nine 
in the 1905. 1913 and 1920 editions of The Voices of Spring. The 1927 versions of Oeuvre were given as the basic text, and the earlier versions were quoted in a fragmentary manner, and discussed in the commentaries.

Although a close analysis shows that the authorial sequence had its unique logic, the subsequent history of publishing Maironis' poetry testifies that the editors created four new structural models of the collection. Due to the frequent reprints of The Voices of Spring with large print runs, a socio-cultural image of the collection was formed that was quite different from the authorial image. As such, a contemporary editor of Maironis faces several problematic alternatives, which can be summed up in the following pattern:

1. When publishing the latest authorial version of the poems, they should be arranged in the sequence of the 1927 edition of Oeuvre, even though this does not correspond with the dominant, long-standing and meaningful title The Voices of Spring, and the readers of Maironis do not recognize the genre title Lyrics; moreover, the latter (sub)title correlates with the volume of Oeuvre and would be more suitable for a many-volume edition of the Maironis corpus than for a separate collection of poems 15

2. When publishing the collection of The Voices of Spring, it would be appropriate to choose the concept of authorial composition that corresponds to this title (i.e. maintaining the sequence of the 1920 edition), but that would not include nineteen later poems. Furthermore, this sequence has an inner conflict with the latest authorial versions of the poems.

3. When publishing any earlier versions of the poems as the collection The Voices of Spring rather than versions of the 1927 Oeuvre edition, the author's will would be ignored, the most well-polished variants that have "caught up" with the language modernization would have to be discarded, and a conflict with the long-standing reception of separate poems would arise.

These alternatives would be partly annihilated in a digital edition, which would allow the reader to see and compare any authorial sequence and corresponding versions of the poems, as well as their historical development. However, the transformation of the collection The Voices of Spring into Oeuvre that plays a different socio-cultural role and has a different bibliographical and linguistic code, performed by the poet himself, is fundamental. Thus it is an inconceivable task to find a model of an edition that minimises the editorial co-authorship that would integrate both the compositional concept of The Voices of Spring and the latest versions of the texts, i.e. the versions of Oeuvre.

poems, which were censored out by the Soviets.

15 In the 1952 edition, Lyrics was added as a subtitle to The Voices of Spring. This created a new combination of a title, subtitle, versions of poems and overall composition of the collection. In one of the more recent editions, this combination of a title, subtitle, and composition was repeated, but the versions of the poems are presented according to the 1927 edition (Maironis 2012). This way, the variety of basic components of the textual and bibliographic code is increased once again. 
Another editorial challenge arises from one more editorial perspective that could consider the authorial use of his poetry as a means of revenge. In order to pursue this curious idea, I should first discuss the bibliographical code of The Voices of Spring in greater detail ${ }^{16}$ The first publication of the 1895 collection had a rather modest printing quality and a small size, which was understandable because of its clandestine nature (Maironis 1895a). Nevertheless, the edition contained ornate initial letters and several vignettes from the printing house's standard kit. The publication of 1905 boasted even more opulent drawn initials and slightly better paper, but in this case an original visual solution was not offered either. A coloured carton-paper cover with the author's portrait (by the famous artist Antanas Žmuidzinavičius, 1876-1966) and his two other photographs from different periods in inserted plates allow us to interpret the third edition of The Voices of Spring as giving particular emphasis on Maironis' person. More abundant vignettes were not created especially for this book, but they are larger and more complex, and the layout is more spacious. Yet, the first three editions of the poetry collection are nothing out of the ordinary in the stylistic and technological context of the design of printed production of the given period and specific printing houses.

The 1920 edition of The Voices of Spring has a lot of marked differences from the earlier editions. The extraordinary nature of this edition is enhanced by two historical circumstances. Firstly, unlike in earlier cases, Maironis himself chose and commissioned its visual materials - illustrations and photographs - and took decisions regarding their arrangement (materials prepared by the author preserved in the publisher's copy; see Maironis 1918). Secondly, Maironis' efforts did not go unnoticed - the book's design created a stir in the cultural and religious circles of that time, was criticized in published reviews, and caused private gossip both for aesthetic and moral reasons.

What was it that public opinion was so critical about? A very colourful cover blended art nouveau elements with neo-romanticist country sugariness (see Figure 3). The author of the cover design and some of the illustrations was an amateur artist Kazys Šimonis (1887-1978), whose folksy decorations and forthright symbolism was quite to the taste of the first-generation urban residents of the young national republic. Added to this, elements of Šimonis's graphic art, details of Raphael's paintings, primitive national ornaments, art nouveau-style ladies, flowers from greeting cards and photographs, were all mingled together on the book's pages. Moreover, almost every page had a different layout (see Figure 4), and some copies were printed on better quality paper with dark green instead of black ink.

“Neither spit nor swallow. There hasn't been a single book in the Lithuanian

16 This description is necessary because so far no bibliographic works have been published that analyse (or at least described in detail) the bibliographic code of Maironis' books. There is only one recent article that looks at the design of Voices of Spring, but does this for the most part in the context of the Lithuanian imagery of spring (Jankevičiūtè 2019). 


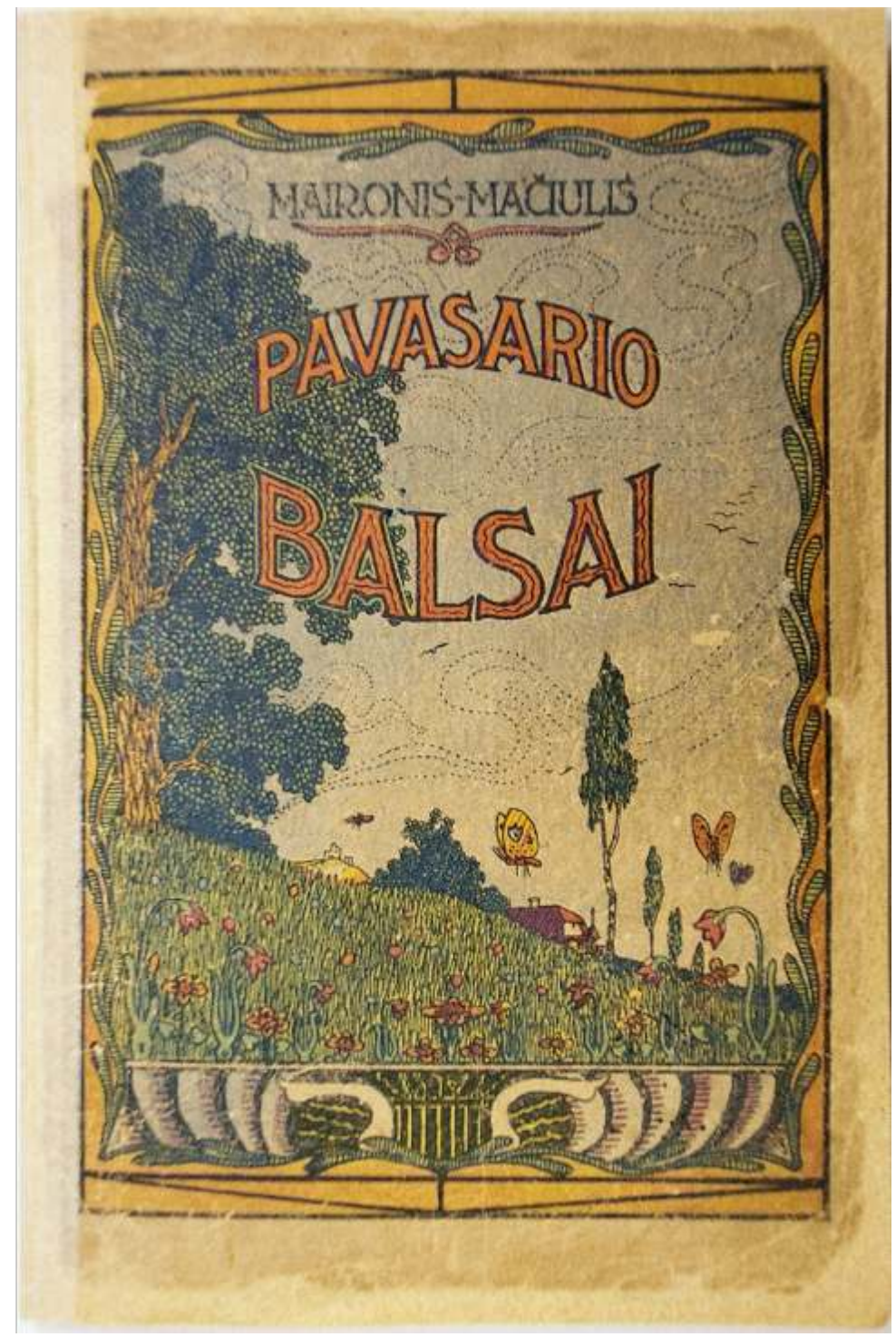

Figure 3: Maironis 1920, cover by Kazys Šimonis 


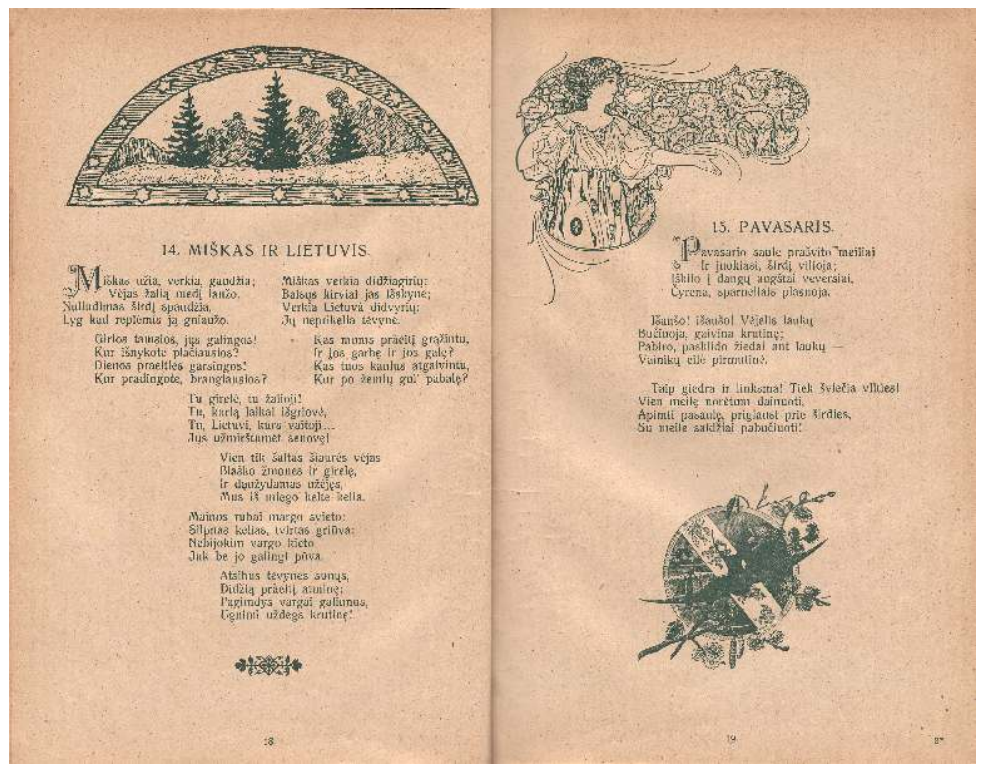

Figure 4: Maironis 1920 18-19

language so lavishly illustrated, so pretentious and so clumsily published" (Sruoga 1920.120). In his review, the famous Lithuanian writer and theatre figure Balys Sruoga (1896-1947) resented the visual cacophony of the edition. Setting aside all the other oddities of illustrations, I would note that the poem "Ant Neapolio užtakos" [In the Bay of Naples], in which Vesuvius is mentioned, was illustrated with a photograph of a landscape of the Lithuanian plains. Why do I assume that by choosing the superfluous, heterogeneous and kitschy design, the author was taking revenge? And on whom? In 1910, Maironis bought a late Baroque mansion in the very centre of Kaunas, City Hall Square. At the poet's request, the interior decoration of the first-floor rooms was made by an archaeologist, public figure and creator of symbols of the national state Tadas Daugirdas (1852-1919). On the one hand, the interiors of Maironis' house, which was much frequented by guests, became a model of national-style decoration for Lithuanian city dwellers. On the other, artists who had studied in the West and intellectuals of the younger generation made ironic remarks about the eclectic décor - a mishmash of attributes of noble and peasant culture and pompous neo-romanticist paintings.

Around the same time, the poet's works were increasingly more often termed as old-fashioned. "Goodnight, Maironis!" (Šmulkštys-Paparonis 1920) — these words summarized a review of an epic work by Maironis that came out in the same period. Likely, by the bibliographic code of the 1920 edition of The Voices 


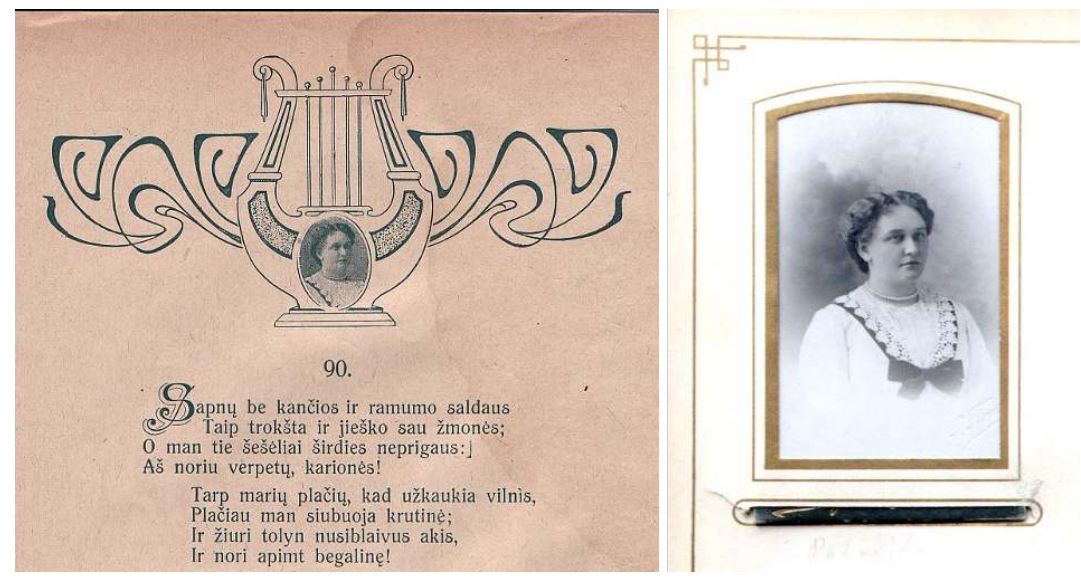

Figure 5: Apolonija Petkaitè in Maironis 1920. 94 (left); and in Maironis's private album, Maironis Lithuanian Literature Museum, No. 2264a (right).

of Spring, the author seemed to declare that while people might make fun of his work and lifestyle, it was still he who set the trends in Lithuania, and he who would decide what is beautiful. And that just like his poems, the images he had chosen would pave the way for a canon of national aesthetics. As an indirect confirmation of this assumption, I would like to refer to a photo of Maironis' house that was included in the 1920 edition of The Voices of Spring.

Furthermore, there is an even spicier feature of this book. Maironis dedicated several of his poems to women with whom he had close contacts in different periods of his life. In the 1920 edition of The Voices of Spring, two more dedications of this kind appeared. Admittedly, all these dedications were marked with initials only, or else the names were arranged in acrostics. Contrary to this camouflage, however, this edition contained five women's photographs along with landscape photographs. Two of them can be considered mere illustrations of the national costume accompanying patriotic poems. Yet the other women are easily recognizable - it was to them that the poems were dedicated, and these photographs have survived in Maironis' private archive with ambiguous inscriptions. Moreover, a portrait of one girl is set in a vignette representing a lyre, thus very straightforwardly implying that she was the poet's muse (Maironis 1920. 94; see Figure 50. It is appropriate to recall that Maironis was a Catholic priest, to whom celibacy was obligatory. These illustrations provided an even more fertile ground for the rumours that, out of keeping with his class, Maironis had been having intimate relations with several women and was secretly taking care of an illegitimate child.

One should bear in mind that although Maironis was 58 at the time, Lithuania was a very conservative society in the early twentieth century when it comes to 
social customs, and was rather intolerant of romantic affairs - even if they had taken place in the past. So, why did Maironis dare to make this provocation? It would be respectable to tell a noble literary tale of the brave poet's rebellion against the hypocrisy of Victorian morals and a modern individual's declaration of creative and personal freedom. Unfortunately, the reality was most probably much more banal. I would argue that Maironis decided to include photos of real women-muses in the edition after his smouldering hope to be nominated as a bishop had been shattered ${ }^{17}$ Being a prelate and the most famous Lithuanian writer alive, he was not afraid of losing his social status by choosing these illustrations, and could at least in this way take his revenge on the church dignitaries that had disappointed him.

Still, in Oeuvre (the design of which was also ordered by the author) Maironis removed both the dedications to his muses, their portraits, and illustrations in general. By the writer's decision, the colourful dynamics of authorial manipulation of the editions of The Voices of Spring was weighed down by the classical Oeuvre of restrained appearance and temperate composition, which established the image of Maironis' solidity. Ironically, with this turn of circumstances, it was not until recently that the genesis of Maironis' verses and the development of the structure of the collection have been given consistent research attention.

Keeping three main things in mind, that is: 1) the poetic elaboration of the text; 2) the continuous restructuring of the composition of his collections of poetry; and 3) the solutions concerning bibliographical code, Maironis' practice of editing his own works was radically situational. Therefore, any traditional edition may, in the best case, roughly convey only one of those textual constellations. The effort and ability of a poet to change creatively is as important evidence of his talent as the final elaborated version of his poems. Thus, a digital archive that enables a user to encounter every different stage of the development of The Voices of Spring (be that edition, or manuscript) as a unique entirety, that presents a genetic sequence of variants would no longer merely present Maironis' poetics as fragmented, and deconstructed. Instead, the author would appear as more appealing to any contemporary reader, and the edition would be representative of the peripeteias of the creation of modern culture. The digital archive and genetic edition of The Voices of Spring is already prepared and will be publicly available after this article is published ${ }^{18}$ The case of Maironis, in its turn, testifies that the initially perceived stability and continuity of literature may also function in another way, that is, by situational adaptation. In this sense, the sequence of former chameleonic transformations of The Voices of Spring extends when they are transposed to the digital medium.

17 Maironis was particularly hurt by the fact that two prominent nineteenth-century Lithuanian priest writers (Motiejus Valančius and Antanas Baranauskas) had become bishops, just like his younger colleagues, professors at the Theological Academy, the now-Blessed Jurgis Matulaitis and Juozapas Skvireckas, while his own candidacy was rejected several times.

18 To be hosted online at: http://www.pb.flf.vu.lt/ 


\section{Bibliography}

Brazdžionis, Bernardas, 1952. “Redaktoriaus žodis." In Pavasario balsai: Lyrika, authored by Maironis, edited by Bernardas Brazdžionis, Roma: Mons. Pr. Juras, pages 279-95. 17th edition.

Bushell, SAlly, 2005. "Intention Revisited: Towards an Anglo-American 'Genetic Criticism'.” Text 17, pages 55-91.

DAujotyté, Viktorija, 1990. “Maironio poetinès programos visuotinumas." In Maironis, Literatūra ir kalba, volume 21, Vilnius: Vaga, pages 55-68.

Girdzijauskas, Juozas, 1966. Lietuviu eilèdara: Silabinès-toninès sistemos susiformavimas. Vilnius: Vaga.

JABLONSKis, Jonas, 1901. Lietuviškos kalbos gramatika. Rašytojams ir skaitytojams vadovèlis. Paraše Petras Kriaušaitis. Tilžè. [print by O. Mauderodè].

JANKevičIŪtė, GIedre், 2019. "Maironis ir jo Pavasario balsai lietuviškosios pavasario vaizdinijos kontekste." LKMA Metraštis 42, pages 127-53.

KALNAČs, BenEdikTs, ed., 2009. 300 Baltic Writers: Estonia, Latvia, Lithuania: a reference guide to authors and their works. Vilnius: Lietuvių literatūros ir tautosakos institutas.

Kessler, Stephan, 2014. "Maironis' Pavasario balsai (1895) and the Question of Its Romanticism." In Eina garsas: Nauji Maironio skaitymai, edited by Manfredas Žvirgždas, Vilnius: Lietuvių literatūros ir tautosakos institutas, pages 66-75.

KuČINSKIENĖ, AistĖ, 2014. “Ankstyvasis Maironis literatūros lauke: įsišventinimas, kanonizavimas, pozicijų užèmimas." In Eina garsas: Nauji Maironio skaitymai, edited by Manfredas Žvirgždas, Vilnius: Lietuvių literatūros ir tautosakos institutas, pages 250-65.

Maironis, 1885. “Lietuvos vargas.” Auszra 7-8, pages 194-95.

— 1888. "Lietuva." Auszra 7-8, pages 194-95. [Holograph, dedicated to bp. Antanas Baranauskas] Vilnius University Library, Manuscript Department, F1-D68.

, 1891a. Apsakymai apie Lietuvos praeiga. Tilžè: Kasztu Lietuvos mylètojų. [print by O. Mauderodè].

, 1891b. "Daina apie senove." Žemaiczių ir Lietuvos Apžvałga 5, page 35.

, 1891c. "Lietuvos gražybe." Varpas 11, pages 162-63. 
— 1895a. Pavasario Balsai. Tilźeje: Kasztu autoriaus. [print by O. Mauderodè].

—, 1895b. Terp skausmu ị Garbę: Poèma isz dabartiniu laiku. Tilźėje: Spausta kasztu E. Jagamasto. [print by O. Mauderodè].

— 1905. Pavasario Balsai. ir Kur išganymas. Peterburgas: Išleista Lietuvių Laikraščio kaštais, 3rd edition. [print by Golike and Vilborg].

S. Banaitis].

, 1918. Pavasario Balsai ir Kame išganymas. Kaunas, 4th edition. 1913.

[print by S. Banaitis] [authorial copy with revisions - publisher's copy for typesetting of 1920 ed.] Maironis Lithuanian Literature Museum, No. 102103.

—, 1920. Pavasario Balsai. Tilžè: Jagomasto sp. Lituania.

— 1925. Punés kalnas. [Holograph, rough copy] Maironis Lithuanian Literature Museum, No. 20040, ff. 1v, 2r, 2v, 3v, 4v.

—_ 1926. Pavasario Balsai. Tilžè: Jagomasto sp. Lituania. 1920. [Authorial copy with revisions made due preparation of Maironio raštai, 1, 1927 ed.] Maironis Lithuanian Literature Museum, No. 4795.

— 1927. Maironio raštai, 1: Lyrika, volume 6. Kaunas: Raidès spaustuvè.

— 1942. Pavasario balsai, edited by Juozas Ambrazevičius. Kaunas: Valstybinè leidykla.

— 1947. Pavasario balsai, edited by Liucina Starevičiūtè. Kaunas: Valstybinè grožinès literatūros leidykla.

— 1952. Pavasario balsai: Lyrika, edited by Bernardas Brazdžionis. Roma: Mons. Pr. Juras, 17th edition.

- 1963. "Maironis." Lituanus 9(1). Available from: http://www.lituanus.org/1963/63_1_03.htm (Accessed: 2021-03-07).

—, 1976. Pavasario balsai. Vilnius: Vaga.

- 1982. Pavasario balsai. Vilnius: Vaga.

— 1986. Pavasario balsai, edited by Rimantè Umbrasaitè. Vilnius: Vaga.

— 1988. Raštai, 2: Poemos, edited by Irena Slavinskaitè. Vilnius: Vaga.

-1995. Pavasario balsai, edited by Irena Slavinskaite. Vilnius: Baltos lankos, 27th edition. 
- 2002. "Maironis." Lituanus 48(3). Available from: http://www.1ituanus.org/2002/02_3_01.htm (Accessed: 2021-03-07).

_ 2012. Pavasario balsai: Lyrika, edited by Manfredas Žvirgždas. Vilnius: Lietuvių literatūros ir tautosakos institutas, 28th edition.

_ 2020. Pavasario balsai, edited by Deimantè Cibulskienè. Kaunas: Maironio lietuvių literatūros muziejus.

Naujokaitis, Pranas, 1948. Lietuvių literatūra: Trumpas lietuvių literatūros kursas gimnazijai. Tübingenas: Patria.

Nyka-Niliūnas, Alfonsas, 1962. "Maironio likimo paraštèje." Aidai 7, pages 283-86.

Pokorska-Iwaniuk, Monika, 2014. "Pavasario balsai Maironisa jako cykl poetycki." In Eina garsas: Nauji Maironio skaitymai, edited by Manfredas Žvirgždas, Vilnius: Lietuvių literatūros ir tautosakos institutas, pages 114-31.

Reynolds, L.D. and N.G. Wilson, 1991. Scribes E Scholars: A Guide to the Transmission of Greek $\mathcal{E}$ Latin Literature. Oxford: Clarendon Press, 3rd edition.

Sauka, Donatas, 1998. "Ein Gedicht von Maironis im Vergleich zum Werk Goethes." Annaberger Annalen 6, pages 79-88.

ŠEINA, VIKTORIJA, 2016. "Maironio kanonizacijos dinamika XX a. I pusès lietuvių literatūros kritikoje." Colloquia 37, pages 49-71.

Shillingsburg, Peter L., 1991. "Text as Matter, Concept, and Action." Studies in Bibliography 44, pages 31-82.

Shillingsburg, Peter L, 2017. Textuality and Knowledge: Essays. University Park (PA): The Pennsylvania State University Press.

SlavinSKaitė, Irena, 1987. "Maironis (1862-1932)." In Raštai, 1: Lyrika, authored by Maironis, edited by Irena Slavinskaitè, Vilnius: Vaga, pages 8-48.

ŠmulKštys-Paparonis, Antanas, 1920. "Del Maironio poemos 'Mūsų vargai'." Laisvé 169, page 4 .

SpeičYté, Brigita, 2012. Anapus ribos: Maironis ir istorine Lietuva. Vilnius: Lietuvių literatūros ir tautosakos institutas.

_ 2019. "Maironio Pavasario balsai: lyrikos rinkinys." In Maironio balsai: Kūryba, veikla, atmintis, edited by Manfredas Žvirgždas, Vilnius: Lietuvių literatūros ir tautosakos institutas, pages 29-141.

SRuOGA, Balys, 1920. “Knygoms apginti (Del Maironies Mačiulio ‘Pavasario balsų' penktojo leidimo)." Skaitymai 1, pages 118-21. 
Stroebel, William, 2018. "Some Assembly Required: Suspending and Extending the Book with Cavafy's Collections." Book History 21, pages 278-316.

VenCKIENĖ, Jurgita, 2006. “Bendrinè kalba: tarmès pasirinkimas ir kodifikacija katalikiškoje ir pasaulietineje periodikoje (1889-1905)." Archivum Lithuanicum 8, pages 191-208.

— 2012. "Jono Mačiulio-Maironio raštų rašyba ir kalba: Jauniaus sekejjo dinamika." Archivum Lithuanicum 14, pages 9-42.

—_ 2018. “Maironio Pavasario balsai (1895-1927): kaip kito eilèraščiu kalba." Archivum Lithuanicum 20, pages 209-34.

ZaborsKaité, VANDA, 1987. Maironis. Vilnius: Vaga, 2nd edition.

ŽvirgžDAs, ManfredAs, 2012. "Po Maironio ženklu." In Pavasario balsai: Lyrika, authored by Maironis, edited by Manfredas Žvirgždas, Vilnius: Lietuvių literatūros ir tautosakos institutas, pages 7-56. 28th edition. 